\title{
Elon Musk and SpaceX: A Case Study of Entrepreneuring as Emancipation
}

\author{
Steven Muegge and Ewan Reid
}

\author{
"We are at a turning point in the history of space" \\ exploration and development. ... The established \\ state-run industrial space sector is no longer the only \\ game in town.
}

Gary Martin,

Director of Partnerships, NASA Ames Research

\begin{abstract}
Elon Musk and SpaceX are central to the profound change underway in the space industry, opening up the sector to entrepreneurship and innovation by non-traditional new entrants. We employ the emancipation perspective on entrepreneuring as a theoretical lens to describe, explain, and interpret the entrepreneuring activities of Musk to launch and grow SpaceX. Applying an event study approach that combines case methods and process theory methods on publicly-available sources, we develop six examples of seeking autonomy, seven examples of authoring, and four examples of making declarations- the three core elements of the emancipation perspective on entrepreneuring. Our work contributes to the theory and practice of innovation by adding to the corpus of descriptive case studies that examine entrepreneuring as an emancipatory process. Our results and our method will also also be of interest to space industry entrepreneurs, investors, analysts, managers, policy-makers, and officers at governmental space agencies.
\end{abstract}

\section{Introduction}

The article presents results from a case study of the entrepreneuring activities undertaken by Elon Musk between 2001 and 2015 to launch and grow Space Exploration Technologies Corporation (SpaceX, https://www.spacex.com/), a private commercial spaceflight venture. We employ the emancipation perspective on entrepreneuring (Rindova et al. 2009) as a theoretical lens to identify, describe, and interpret examples of seeking autonomy, authoring, and making declarations- the three core elements of entrepreneuring emancipation. Our work contributes to the theory and practice of innovation by adding to the corpus of descriptive case studies that examine entrepreneuring as an emancipatory process.

First proposed by Rindova et al. (2009) in the Academy of Management Review, Jennings et al. (2016, p. 81) describes the emancipation perspective as "groundbreaking," with "paradigm-shifting potential" for understanding entrepreneurship and innovation.
While theory-building requires careful observation and accurate description (Christensen \& Raynor, 2003) undertaken by engaged scholars (Van de Ven, 2007), the features of both description and explanation are strengths of case study research designs (Yin, 2014; Eisenhardt et al. 2016). Thus, we argue that a corpus of well-designed and rigorously-executed case studies that employ the emancipation perspective to examine highimpact technology innovations, could accelerate theorybuilding about technology entrepreneurship and innovation. Nonetheless, there remains a dearth of published case research on these topics (Jennings et al. 2016; Reid, 2018). This paper is the second in a series of case study publications addressing this gap by examining the activities of NewSpace entrepreneurs (Zubrin, 2013; Pekkanen, 2016; Martin, 2017). Our previous paper examined Sir Richard Branson and Virgin Galactic (https://www.virgingalactic.com/) (Muegge \& Reid, 2018) and a forthcoming paper will examine Peter Diamandis and the XPRIZE Foundation (https://www.xprize.org/). 


\section{Elon Musk and SpaceX}

\section{Steven Muegge and Ewan Reid}

The article proceeds as follows. The first section reviews the relevant prior research perspectives on entrepreneuring emancipation. The second section describes the research method, and the third introduces the case of Elon Musk and SpaceX. The fourth, fifth, and sixth sections each present results about one of the three core elements of entrepreneuring: seeking autonomy, authoring, and making declarations, respectively. The seventh section discusses the results, and the eighth section concludes.

\section{Entrepreneuring as Emancipation}

Entrepreneuring refers to "efforts to bring about new economic, social, institutional, and cultural environments through the actions of an individual or group of individuals" (Rindova et al. 2009, p. 477). Entrepreneuring is thus about the creation of something new, not merely about change.

Emancipation refers to "the act of setting free from the power of another" (Webster's Revised Unabridged Dictionary, 1996). The focal point of inquiry is thus the "pursuit of freedom and autonomy relative to an existing status quo" (Rindova et al. 2009, p. 478).

The Rindova et al. (2009) emancipation perspective of entrepreneuring connects these two ideas, emphasizing verbs and actions rather than nouns and things. "We theorize that ... three core elements are central to an emancipatory process" (p. 479):

- Seeking autonomy is the impetus for entrepreneuring- the perceived need of the entrepreneur to break free of or break up perceived constraints

- Authoring is defining new resource arrangements, relationships, and rules of engagement- taking ownership to change positions of power, to realize change-creating intent, and to preserve and enhance emancipatory potential

- Making declarations is about managing interpretations and expectations, mobilizing support, and generating change effects through discursive and rhetorical acts about intended change

The emancipation perspective emphasizes change creation: wealth creation may feature also, but it need not dominate the intended change. Rindova et al. (2009) write, "We believe that entrepreneurship research perhaps has become a bit too narrowly focused on wealth creation via new ventures" (p. 478) and "The implied opposition between emancipatory projects to create change and a 'hard-nosed business strategy' is a false one" (p. 483).

\section{Method}

Our research problem is the identification and description of the NewSpace entrepreneuring activities undertaken by Musk using the framework and constructs of the emancipation perspective on entrepreneuring. Our field setting is the space industry, which is currently in the midst of resurgence and profound change (Reid, 2018b, 2019; Davenport, 2018; Fernholz, 2018). Davenport (2016, p. 3) writes:

\section{"Another space race is emerging, this time among a class of hugely wealthy entrepreneurs who have grown frustrated that space travel is in many ways still as difficult, and as expensive, as ever. Driven by ego, outsized ambition and opportunity, they are investing hundreds of millions of dollars of their own money in an attempt to open up space to the masses and push human space travel far past where governments have gone".}

Martin (2017), Director of Partnerships for the NASA Ames Research Center, writes: "The established state-run industrial space sector is no longer the only game in town" (p. 3).

Our research design is an event study (Van de Ven, 2007), combining case methods (Yin, 2014; Eisenhardt et al. 2016) with process theory methods (Poole et al. 2000) to operationalize the core constructs of the emancipation perspective. We focus on a single entrepreneur and their venture using publicly-available data sources. Our source for identifying events was a book-length biography, Elon Musk: Tesla, SpaceX, and the Quest for a Fantastic Future (Vance, 2015). Musk cooperated in the production of the book by providing interviews, documents, and access to other people, but did not review the book prior to publication or exert editorial control.

We employed NVivo qualitative data analysis (QDA) software, a set of coding rules, and a common framework for specifying events. Our analysis began with incident coding of the main source to identify and 


\section{Elon Musk and SpaceX}

\section{Steven Muegge and Ewan Reid}

tag relevant passages of text, followed by event coding of the incidents to identify and specify a set of emancipation events. We then enfolded additional evidence, context, and perspectives from other sources, including published interviews with Musk, press releases from the SpaceX website, and articles about Musk and SpaceX. Each event record in the QDA software preserved links to evidence in the source material.

Our use of publicly-available sources (rather than primary interviews) is similar to the approach of Rindova et al. (2009) in the seminal article about emancipation. First-hand accounts by the focal entrepreneur are triangulated with stories from others and with other publicly-available records.

Our outcome is a set of case results, presented in a narrative form, structured using the constructs of the emancipation perspective. We report seventeen emancipation events:

- Six seeking autonomy events as the impetus for entrepreneurship, describing Musk's perceived need to break free of or break up a perceived constraint

- Seven authoring events of Musk taking ownership by defining relationships, arrangements, and rules of engagement, and changing the positions of power

- Four making declarations events of Musk's discursive and rhetorical acts about changecreating intent

\section{Elon Musk and Space Exploration Technologies Corporation (SpaceX)}

According to the company website: "SpaceX designs, manufactures and launches advanced rockets and spacecraft. The company was founded in 2002 to revolutionize space technology, with the ultimate goal of enabling people to live on other planets."

Elon Musk was born in South Africa in 1971, moved to Canada in 1989 to attend Queen's University (Kingston, Ontario), then transferred to the University of Pennsylvania in 1991. After completing degrees in economics and physics, he moved to to Silicon Valley in 1995, where he launched and exited two technology startups. Vance (2015, p. 14) summarizes this period prior to SpaceX, as follows:
"Fresh out of college, he founded a company called Zip2-a primitive Google Maps meets Yelp. That first venture ended up a big, quick hit. Compaq bought Zip2 in 1999 for $\$ 307$ million. Musk made $\$ 22$ million from the deal and poured almost all of it into his next venture, a startup that would morph into PayPal. As the largest shareholder in PayPal, Musk became fantastically well-to-do when eBay acquired the company for $\$ 1.5$ billion in 2002".

Musk moved to Los Angeles in 2001. Regarding this move, Vance writes, "While Musk didn't know exactly what he wanted to do in space, he realized that just by being in Los Angeles he would be surrounded by the world's top aeronautics thinkers. They could help him refine any ideas, and there would be plenty of recruits to join his next venture" (p. 99). One of those people was Robert Zubrin, an aerospace engineer, advocate of human exploration of Mars, and co-founder of The Mars Society (https://www.marssociety.org). Like Musk, Zubrin was frustrated by the priorities and slow progress at NASA, saying, "America's human spaceflight program is now adrift" (2013, p. 24). He nevertheless noted "a bright spot on the horizon in the form of a wave of entrepreneurial activity, most particularly that of the SpaceX company" (p. 54).

Zubrin (2013, p. 56) describes some of his impressions of Musk:

"Unlike the other would-be space magnates, Musk did not simply throw an expendable chunk of his fortune into the game; he put the full force of his talent and passion into it. When I met Musk in 2001, he had a good grasp of scientific principles, but knew nothing about rocket engines. When I visited him at his first small factory in Los Angeles in 2005, he knew everything about rocket engines. By the time of my next visit a few years later, he had experienced two straight failures of his first launch vehicle, the Falcon 1, but was determined to push on despite the blows to his finances and reputation. It is this level of commitment that has made all the difference. None of the other billionaire-backed space startups have ever cleared the tower. SpaceX has delivered Cargo to the space station and will soon be sending people".

By all close accounts (for example, Zubrin, 2013; 


\title{
Elon Musk and SpaceX
}

\author{
Steven Muegge and Ewan Reid
}

Table 1. Timeline of Elon Musk and SpaceX (compilation of sources)

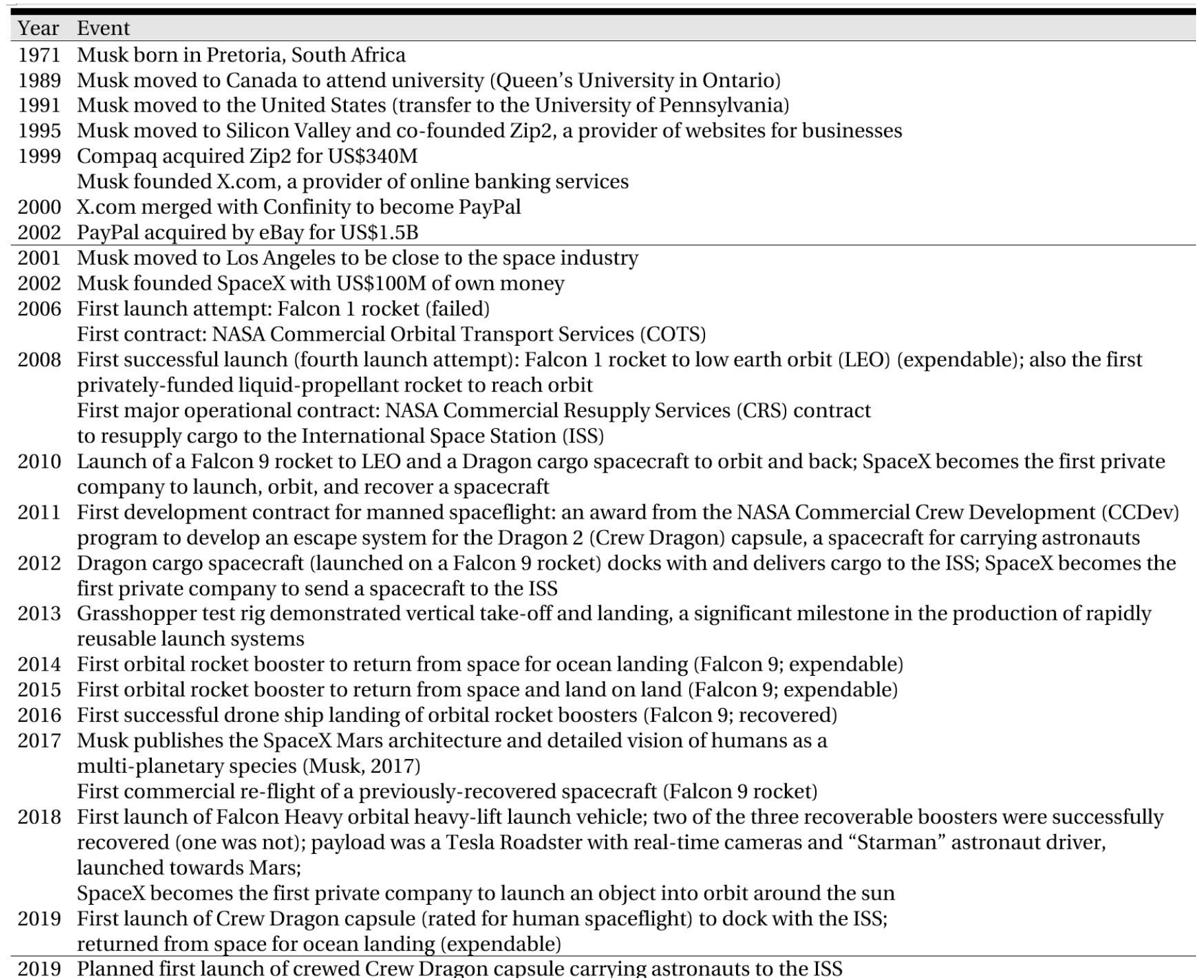

Diamandis \& Kotler 2015; Vance, 2017), Musk's ultimate ambition, even before founding SpaceX in 2002, was sustainable human settlement on Mars, thus making humans a multi-planetary species (Musk, 2017).

Table 1 reports a timeline of Musk's early entrepreneurial activities, significant milestones for SpaceX, and stated future goals. Our emphasis here is exclusively SpaceX. Musk's other business and not-forprofit ventures subsequent to founding SpaceX-including Tesla (2003), SolarCity (2006), Hyperloop (2012), OpenAI (2015), Neuralink (2016), and The Boring Company (2016), are therefore not part of the article's scope. The following three sections each introduce one of three core elements in the emancipation perspective. They report examples identified from the main source (Vance, 2015), and supported with further details from additional sources. Page numbers refer to Vance (2015) unless otherwise noted. Because our main source for identifying emancipation events was published in 2015, all of the examples that follow began prior to 2015 .

\section{First Core Element: Seeking Autonomy}

Seeking autonomy is the entrepreneurial impetus of the emancipation perspective- the perceived need of the entrepreneur to break free of or break up a perceived constraint in the environment (Rindova at al. 2009). For 


\section{Elon Musk and SpaceX}

\section{Steven Muegge and Ewan Reid}

Schumpeter (1942), creative destruction was a means of entrepreneurship, but in the emancipation perspective it is also a goal: an entrepreneur seeks escape by overcoming or removing perceived constraints that "can be of an intellectual, psychological, economic, social, institutional, or cultural nature" (Rindova et al. 2009, p. 479).

A first example of seeking autonomy was Musk's perceived need to break free of the constraint that space had become boring. People "had grown cynical about anything novel happening in space again" ( $p$. 103). "Musk would inspire people to think about exploring space again by making it cheaper" (p. 108). "He wanted to inspire the masses and reinvigorate their passion for science, conquest, and the promise of technology" (p. 101). Musk (2017, p. 46) writes: "I want to make Mars seem possible-make it seem as though it is something that we can do in our lifetime. There really is a way that anyone could go if they wanted to."

A second example was Musk's perceived need to do something that matters, breaking free of the constraint that the Internet runs on advertising and low-impact problems, and that top talent is too-often wasted on selling more ads. Musk states: "There are probably too many smart people pursuing Internet stuff, finance, and law" (p. 9). "Where Mark Zuckerberg wants to help you share baby photos, Musk wants to... well... save the human race from self-imposed or accidental annihilation” (p. 17). “[Musk's] empathy is unique. He seems to feel for the human species as a whole without always wanting to consider the wants and needs of individuals" (p. 363).

A third example was Musk's perceived need to be CEO in control of his own company. Musk "wanted to be CEO" (p. 67), but "at both Zip2 and PayPal, the companies' boards came to the conclusion that Musk was not yet CEO material" (p. 91). Both companies "had been ripped away from Musk and given to someone else to run" (p. 97). Musk founded SpaceX with US\$100M of his own money from the acquisition of PayPal by eBay in 2002. Launching, growing, and exiting two previous companies provided credibility, and investing his own money provided autonomy. "With such a massive up-front investment, no one would be able to wrestle control of SpaceX away from Musk as they had done at Zip2 and PayPal" (p. 116). In a 2013 email to staff, Musk wrote: "Creating the technology needed to establish life on Mars is and always has been the fundamental goal of SpaceX. If being a public company diminishes that likelihood, then we should not do so until Mars is secure” (p. 260).

A fourth example was breaking free of dependency on Russian launch vehicles. "The Russians were the only ones with rockets that could possibly fit within Musk's budget" (p. 103). Instead of contracting out, SpaceX built the Falcon rocket for small payload missions: "Musk would inspire people ... by making it cheaper to explore space" (p. 108).

A fifth example, one that was central to Musk's identity and ultimate ambitions, was breaking free of the obvious constraint that there were no humans on Mars. Musk was frustrated that humans had no way to travel to Mars, and even more so, that there were no credible projects to get humans to Mars at any point in the future. Musk states: "At first I thought NASA just had a badly designed website. Why else couldn't you find this critical piece of information that would obviously be the first thing you'd want to know when you go to NASA.gov? But, it turned out, NASA had no plans for Mars. In fact, they had a crazy policy that didn't even let them talk about sending humans to Mars" (Diamandis \& Kotler, 2015, p. 118). Musk also dreamed bigger, not only to travel to Mars, but to live there: "The thing that's important in the long run is establishing a selfsustaining base on Mars. In order for that to work- in order to have a self-sustaining city on Mars- there would need to be millions of tons of equipment and probably millions of people" (p. 332).

A sixth example was breaking up the entrenched notion that space is special-not like other industries- implying a set of constraints that prohibited practices that were effective elsewhere. Anything designed and built for space is expensive and takes a long time (p. 114), and rockets and capsules were used only once. "So long as we continue to throw away rockets and spacecraft, we will never have true access to space" (p. 257). Musk therefore demanded reusable rockets, reusable capsules, and massive cost reduction:

- SpaceX rockets "push their payload to space and then return to Earth and land with supreme accuracy on a pad floating at sea or even their original launchpad" (p. 217).

- "SpaceX proved that the Falcon 9 could carry the Dragon capsule into space and that the capsule could be recovered" ... "The Dragon 2 will ... [use] SuperDraco engines and thrusters to come to a gentle stop on the ground. No more landings at sea. No more throwing spaceships away" (p. 254, 


\title{
Elon Musk and SpaceX
}

\author{
Steven Muegge and Ewan Reid
}

257).

- "Musk's goal is to use manufacturing breakthroughs and launchpad advances to create a drastic drop in the cost of getting things to space" (p. 217).

Consistent with the emancipation perspective on entrepreneuring, seeking autonomy was an impetus for action. Musk was driven to action by at least six perceived constraints: (1) space had become boring, (2) profitable tech companies too often address low-impact problems, (3) founder-entrepreneurs give up control of successful companies, (4) launches required Russian launch vehicles, (5) there were no humans on Mars, and no credible plans to send humans there, and (6) shared belief that practices driving massive cost-reductions in other industries would not work in space. He sought escape from these constraints by launching SpaceX- to inspire, to do something that matters, to be in control, to demonstrate that change is possible, and ultimately, to put humans on Mars.

\section{Second Core Element: Authoring}

Authoring refers to taking ownership by defining relationships, arrangements, and rules of engagement, and changing the positions of power. "Authoring does not refer to an outright rejection of all established norms and forms of authority but, rather, designing arrangements that support the change-creating intent of the entrepreneuring individual" (Rindova et al. 2009, p. 484). The authoring entrepreneur positions an entrepreneurial project in a system of resource relationships with resource holders. This contrasts with the opportunity recognition and creation themes prevalent in entrepreneurship research.

A first example of authoring was Musk joining the network. Prior to 2001, Musk was an outsider to the space industry. Musk's 2001 move from Silicon Valley to Los Angeles gave him access to the space industry (p. 97). Musk joined social networks: he donated to the Mars Society and Mars research (p. 100), joined the Mars Society board of directors, announced founding the Life to Mars Foundation (p. 102), discussed investing $\$ 20 \mathrm{M}$ to $\$ 30 \mathrm{M}$ in a Mars project (p. 103), and built connections with ambitious engineers (p. 111).

A second example was Musk's (unsuccessful) attempt to buy Russian missiles. Launches required specialized launch vehicles such as Russian Soyuz rockets. In 2002, "Musk intended to buy a refurbished intercontinental ballistic missile, or ICBM, from the Russians and use that as his launch vehicle" (p. 104). Musk met with Russians twice in Moscow and once in California. He was willing to pay $\$ 20 \mathrm{M}$ for three ICBMs, but did not reach a deal (pp. 106-107). This was a novel approach that had not previously been attempted.

A third example was organizing SpaceX as a Silicon Valley space company. "Musk felt that the space industry had not really evolved in about fifty years. The aerospace companies had little competition and tended to make supremely expensive products that achieved maximum performance. They were building a Ferrari for every launch" (p. 114). When he founded SpaceX in 2002 with US $\$ 100 M$ of his own money, he brought with him a Silicon Valley way of thinking. Vance describes how "[Musk] had taken much of the Silicon Valley ethic behind moving quickly and running organizations free of bureaucratic hierarchies and applied it to improving big, fantastic machines and chasing things that had the potential to be the real breakthroughs we'd been missing" (p. 14). Musk set "insanely ambitious timelines" (p. 114), used open-concept offices where scientists and engineers worked alongside welders and machinists ( $p$ 113), hired young overachievers fresh from college for rank-and-file engineers and poached top engineers from Boeing, Lockheed Martin, and Orbital Sciences (p. 120), contracted with suppliers outside of the aerospace sector (p. 132), and "never relented in asking his employees to do more and be better" (p. 131). "The only way to keep up", explains Vance, "was to do what SpaceX had promised from the beginning: operate in the spirit of a Silicon Valley startup" (p. 130).

A fourth example was utilizing unconventional launch facilities. Launch tests traditionally happened at air force bases, imposing high costs and long wait times. Musk instead procured a former U.S. military missile test site on the Kwajalein Island (Kwaj) between Guam and Hawaii in the Marshall Islands, and adapted it to his needs (p. 135).

A fifth example was creating the SpaceX system as an end-to-end modular engineering platform (Baldwin \& Clark, 2000; Muegge, 2013; Gawer \& Cusumano, 2014) of launch vehicles, capsules, and engines that were all designed, manufactured, assembled, and tested at SpaceX facilities. Components included the Falcon 1, Falcon 5, Falcon 9, Falcon Heavy, and ITS Launch Vehicle, the Dragon and Dragon 2 capsules, and the Merlin, Kestrel, Draco, and SuperDraco engines. (These are the component names used by Vance for the components of the SpaceX system. As of 2019, several 


\title{
Elon Musk and SpaceX
}

\author{
Steven Muegge and Ewan Reid
}

components have been renamed, new components have been added, and some components are no longer used. However, the principle of a modular platform architecture remains deeply entrenched). SpaceX sourced key capabilities in-house and "increased its internal welding capabilities so that it could make the fuel tanks in [a SpaceX facility] and ditch Spincraft [a suppler]" (p. 132). "[Musk] doesn't want to handle a few launches per year or to rely on government contracts for survival. Musk's goal is to use manufacturing breakthroughs and launchpad advances to create a drastic drop in the cost of getting things to space" (p. 217). Musk's ambitions about Mars shaped even the earliest design decisions about system architecture and components intended for low Earth orbit: "NASA researchers studying the Dragon design have noticed several features of the capsule that appear to have been purpose built from the get-go to accommodate a landing on Mars ... It could be feasible for NASA to fund a mission to Mars in which a Dragon capsule picks up samples and returns them to Earth" (p. 235).

A sixth example was commercial contracts. Prior to SpaceX, NASA contracted only with traditional aerospace and military suppliers. In 2006, SpaceX contracted with NASA and the U.S. Military to develop technology, and in 2008, to operate missions. In 2012, a Dragon capsule became the first private spacecraft to dock with the International Space Station (Chang, 2012). In 2019, a Crew Dragon capsule became the first private spacecraft rated for human transportation to dock with the ISS (O'Callaghan, 2019); it returned successfully to earth a few days later for an ocean landing (Wall, 2019). SpaceX expects to transport a human crew to the ISS later in 2019.

A seventh example was a viable plan for humans as an interplanetary species. If a catastrophic event were to render Earth unfit for human life, neither human civilization nor the human species would survive. "Musk's ultimate goal" according to Vance, is "turning humans into an interplanetary species. This may sound silly to some, but there can be no doubt that this is Musk's raison d'etre" (p. 331). Musk (2017, p. 46) writes:

\footnotetext{
"Why go anywhere? I think there are really two fundamental paths. History [is] going to bifurcate along two directions. One path is we stay on Earth forever, and then there will be some eventual extinction event. I do not have an immediate doomsday prophecy, but eventually, history suggests, there will be some doomsday event. The alternative is to become a space-bearing civilization
}

\section{and a multi-planetary species, which I hope you} would agree is the right way to go."

Consistent with the emancipation perspective on entrepreneuring, Musk took ownership by defining new arrangements in place of the established status quo of the traditional space industry. He first became embedded in the social communities of people in the space industry through action and investment, then sought to privately obtain unconventional launch vehicles, then launched SpaceX with his own personal funds as a Silicon Valley space company, utilizing unconventional launch facilities, developing a modular platform of re-usable components, and securing commercial contracts, with an ultimate goal of making humans an interplanetary species. Musk's SpaceX status quo operated under different rules and arrangements than the traditional space industry status quo that it displaced, and preserved emancipatory potential for continued change.

\section{Third Core Element: Making Declarations}

Making declarations refers to "unambiguous discursive and rhetorical acts regarding the actor's intentions to create change" ... "[d]eclarations are intended for specific audiences and are bound by customs of rhetoric, speaking, and listening" (Rindova et al. 2009, p. $485,486)$. Unlike legitimation activities that disguise differences, entrepreneuring may involve exposing contradictions and differences to generate stakeholder support for an intended change in the status quo. Contestations from others may be an inevitable consequence of declarations: "The process of declaration and contestation ... is also one of meaning and rhetoric and ultimately of altering societal beliefs about the very nature of things" (p. 486). The entrepreneur making declarations positions an entrepreneurial project within the web of meaning within which stakeholders interpret the value of products and activities.

A first example of making declarations was Musk's commitment and persistence to building a SpaceX launch vehicle. After failing to secure a Russian missile in 2002, Musk declared: "I think we can build this rocket ourselves" (p. 107). The SpaceX website boldly stated: "SpaceX is privately developing the entire Falcon rocket from the ground up, including both engines, the turbopump, the cryogenic tank structure and the guidance system" (p. 118). Initial reactions were tepid: "As word travelled around the space community about Musk's plans, there was a collective ho-hum [from people who had seen this situation before]... The techies usually 


\title{
Elon Musk and SpaceX
}

\author{
Steven Muegge and Ewan Reid
}

ended up spending the rich guy's money for two years, and then the rich guy gets bored and shuts the thing down" (p. 108). Musk nonetheless persisted, spending his own money.

A second example was Musk's commitment to persevere. Musk vowed to continue despite three failed test launches and severe time and cost overruns, declaring "I will spend my last dollar on these companies. If we have to move into Justine's parents' basement, we'll do it" (pp. 198-199). He made confident statements to employees and the public after each setback. "It took six years- about four and a half more than Musk had once planned- and five hundred people to make this miracle of modern science and business happen" (p. 203). The fourth test launch finally succeeded in 2008, when "SpaceX simply did not have enough money to try a fifth flight" (p. 200). "When the launch was successful, everyone burst into tears" (p. 203). Musk told Diamandis \& Kotler (2015, p. 122): "Even if the probability of success is low, if the objective is really important, it's worth doing."

A third example was making declarations about a new paradigm in the space industry. Musk declared that SpaceX would do things differently, and insisted that massive cost reduction was both necessary and possible. Tom Mueller explained: "People thought we were crazy. At TRW, I had an army of people and government funding. Now we were going to make a low-cost rocket from scratch with a small team" (p. 116). "The whole situation was ludicrous. A start-up rocket company had ended up in the middle of nowhere trying to pull off one of the most difficult feats known to man" (p. 137). Musk persevered and succeeded. By 2015, "SpaceX spent $\$ 2.5$ billion to get four Dragon capsules to the ISS, nine flights with the Falcon 9, and five flights with the Falcon 1. It's a price-per-launch total that the rest of the players in the industry cannot comprehend let alone aspire to" (p. 247). Musk (2017) detailed the SpaceX Mars vision of humans as a multiplanetary species:

"As we show that this is possible and that this dream is real-it is not just a dream, it is something that can be made real-the support will snowball over time."

A fourth example was making declarations that SpaceX would remain privately held to pursue its ambitious goals of making humans an interplanetary species. Musk wrote a 2013 letter to SpaceX employees about the timing of going public (p. 260), and made consistent statements about staying private: "For those who are under the impression that they are so clever that they can outsmart public market investors and would sell SpaceX stock at the 'right time,' let me relieve you of any such notion." Zubrin (2013) writes: "At SpaceX, initially all-and still a significant fraction today-of the funds spent have been Musk's. In short, SpaceX spends money as like it is its own-because much of it is" (pp. 57-58). Musk (2017, p. 57) writes:

"The main reason I am personally accumulating
assets is in order to fund this. I really do not have
any other motivation for personally accumulating
assets except to be able to make the biggest
contribution I can to making life multi-planetary."

Consistent with the emancipation perspective on entrepreneuring, Musk made unambiguous discursive and rhetorical acts regarding intentions to make change. Musk's declarations were about building a launch vehicle (and later the SpaceX system) with private funds, persevering despite set-backs, doing things differently, and remaining privately-held. Musk's declarations shaped the interpretations of stakeholders about the value and meaning of SpaceX activities and intent for change.

\section{Discussion}

Our research problem was the identification and description of the NewSpace entrepreneuring activities of Elon Musk using the framework and constructs of the emancipation perspective on entrepreneuring. Our solution was a set of seventeen examples of entrepreneuring as emancipation: six examples of Musk seeking autonomy as an impetus for entrepreneurship, seven examples of authoring to enact change, and four examples of making declarations about change-creating intent. Admittedly, these examples may provide an incomplete and partial view of Musk and SpaceX. Nonetheless, we argue that our work here is insightful for theory and practice. In the paragraphs that follow, we discuss and position (1) the results of this case, (2) the implications about the emancipation perspective, and (3) the broader implications about understanding entrepreneurship and innovation.

Our case results, interpreted through the lens of the emancipation perspective on entrepreneuring, portray Musk as driven to action by seeking escape from perceived constraints: space had become boring, tech companies addressed low-impact problems, successful founder-entrepreneurs lost control of their companies, launches required Russian launch vehicles, humans 


\section{Elon Musk and SpaceX}

\section{Steven Muegge and Ewan Reid}

lived only on earth, and practices that had driven massive cost-reduction in other industries were not used in space. SpaceX was the means for liberation: to inspire, to do things that matter, to maintain control, to show change is possible, and to make humans into a multi-planetary species. Musk authored new arrangements in place of the industry status quo, in particular founding SpaceX with personal funds as a Silicon Valley space company, with unconventional facilities, a modular platform of re-usable components, and commercial contracts to develop technology and provide services. Musk made declarations to shape interpretations of stakeholders about the value and meaning of SpaceX activities and intent for change- about building a launch vehicle and the SpaceX system, persevering despite set-backs, doing things differently, and remaining privately-held.

Musk may be an atypical entrepreneur in both attributes and circumstances. In a new epilogue written for the paperback edition, Vance (2017, p. 374) writes that, "Musk does not operate like your typical CEO. He's charging after a personal calling- one that's intertwined with his soul and injected into the deepest parts of his mind." Furthermore, Musk began SpaceX with a personal fortune, a munificent resource environment that is unavailable to most entrepreneurs. We purposely selected Musk and SpaceX as an extreme case in pursuit of fresh insights, following the research design advice of March et al. (1991), Christensen \& Raynor (2003), Van de Ven (2007), Yin (2014), and Eisenhardt et al. (2016). Nonetheless, we found that the emancipation perspective was valid here also in an extreme case for identifying, describing, and explaining Musk's entrepreneuring activities. This suggests that the emancipation perspective may be applicable to entrepreneurship with broad scope conditions (Suddaby, 2010) that include the most extreme outlier cases. Jennings et al. (2016, p. 99) had previously observed that most empirical work utilizing the emancipation perspective has been conducted in developing economies or with marginalized populations. Our results therefore lead us to call also for empirical investigation of entrepreneuring as emancipation in the world's most-developed economies, most-advanced technologies, and mostadvantaged populations. Likewise, our results support the Rindova et al. (2009) assertion that "implied opposition between emancipatory projects to create change and a 'hard-nosed business strategy' is a false one" (p. 483). SpaceX is both a profitable venture inspired by dreams and a social mission with profit potential. Musk simultaneously pursues a bold societal goal while building a successful company. The emancipation perspective thus accommodates social outcomes and wealth creation within the same framework, thereby calling into question the common practice of treating social entrepreneurship as somehow different from "regular" entrepreneurship.

Some of Musk's entrepreneuring activities appear anomalous from a strict wealth-creation perspective. However, these same activities appear coherent and logically consistent when interpreted as emancipatory change creation to escape from perceived constraints. Other theoretical perspectives on entrepreneurship may also offer coherent explanations for some of Musk's activities - for example, entrepreneurial hubris (Hayward et al. 2006) could perhaps account for the relentless perseverance in 2008 for a fourth launch attempt despite three failures and dwindling resources, entrepreneurial effectuation (Saravathy, 2001) could account for organizing SpaceX as a Silicon Valley company in an industry that organized in unfamiliar ways, and entrepreneurial bricolage (Baker \& Nelson, 2005) could account for both the attempt to procure Russian missiles and the use of unconventional launch facilities. A rigorous consideration of hubris, effectuation, bricolage, and other perspectives is beyond the scope of the current article. However, each of these alternative perspectives appears likely to inform only a subset of the seventeen examples of entrepreneuring as emancipation identified here, and each perspective seems incompatible with or unhelpful for explaining other examples. There are at least two broader implications for scholarship. First, researchers of entrepreneurship and innovation phenomena should continue to adopt multiple theoretical perspectives, a tactic advocated by Christensen \& Raynor (2003), Van de Ven (2007), Yin (2014), and others for methodologically rigorous and high-impact management research. Second, the emancipation perspective can provide an organizing framework that accommodates wealth-creation, hubris, bricolage, effectuation, and other perspectives on entrepreneurship and innovation as partial and complementary explanations of the motivations and processes for some entrepreneuring activities. We agree with Rindova et al. (2009, p. 478) that "research that considers both more closely and more broadly the entrepreneurial dreams and efforts to create change in the world may bring us to a fuller, more comprehensive understanding of the processes of discovery, change, value creation, and ultimately wealth creation" especially for technology entrepreneurs. 


\section{Elon Musk and SpaceX}

\section{Steven Muegge and Ewan Reid}

Limitations of this research include the single-case research design, use of a single narrative source for identifying emancipatory events (Vance, 2015), and exclusive reliance on text sources (i.e., no primary interviews or direct observation). We attempted to address the threats to validity and reliability resulting from these limitations by employing the best practices recommended in the case method literature (Yin, 2014; Eisenhardt et al. 2016), and developing additional cases about other entrepreneurs (Reid, 2018a; Muegge \& Reid, 2018) for cross-case comparisons (Eisenhardt, 1989; Yin, 2014). Nonetheless, coding additional sources about Musk and SpaceX could reveal more examples. Future research should develop more cases of entrepreneurs in the space industry to more fully describe this sector and to enable cross-case comparison within the industry, develop more cases in other sectors to enable crosscase comparison between industries, and examine more variables to understand how emancipation relates to other management constructs, and to high-impact research questions about entrepreneurship, innovation, competitive advantage, and benefits to stakeholders.

\section{Conclusion}

This article has employed the emancipation perspective on entrepreneuring (Rindova et al. 2009) to examine the case of Elon Musk and SpaceX, a "Silicon Valley space company" at the centre of profound change underway in an industry that was once the exclusive domain of government, military contractors, and incumbent aerospace companies. Our work adds to the corpus of descriptive case studies that examine entrepreneuring as an emancipatory process, and demonstrates the application of emancipation as a unifying perspective on entrepreneurship and innovation anchored around change creation.

As an entrepreneur, Musk is an outlier in multiple respects. Nonetheless, we showed that the emancipation perspective accommodated our case results within its framework: seeking autonomy as an impetus for entrepreneurship, authoring to enact change, and making declarations about change-creating intent. We also demonstrated the capability for emancipation to enfold other perspectives from the entrepreneurship literature, such as bricolage and effectuation as partial explanations for authoring events, and both wealth-creation and liberation from established social order as possible forms of changecreating intent. We agree with the Jennings et al. (2016) assertion that the emancipation perspective has much potential for new knowledge production and fresh insights in a wide range of management contexts. We argue in conclusion that our results support broad scope conditions for the emancipation perspective that includes the most-advanced technologies, mostdeveloped economies, and most-advantaged entrepreneurs, as well as developing economies and individuals most in need of liberation.

\section{Further Reading}

A previous version of this article was presented at the ISPIM Connects Ottawa conference (April 7-10, Ottawa, Canada), and published in the conference proceedings (Muegge \& Reid, 2019).

This is the second in a series of case studies examining the activities of NewSpace entrepreneurs using the emancipation perspective on entrepreneuring. Results from our case study of Sir Richard Branson and Virgin Galactic were previously presented at the 2018 Portland International Conference on Management of Engineering and Technology (PICMET '18, August 19-23, Honolulu, Hawaii, USA), and published in the conference proceedings (Muegge \& Reid, 2018).

Ewan Reid's Master of Applied Science Thesis (Reid, 2018a) is available online through the Carleton University open access repository (CURVE): https://curve.carleton.ca 


\title{
Elon Musk and SpaceX
}

\author{
Steven Muegge and Ewan Reid
}

\section{References}

Baker, T., \& Nelson, R. E. 2005. Creating Something from Nothing: Resource Construction through Entrepreneurial Bricolage. Administrative Science Quarterly, 50(3): 329-366.

http://dx.doi.org/10.2189/asqu.2005.50.3.329

Baldwin, C. Y. \& Clark, K. B. 2000. Design Rules: Volume 1: The Power of Modularity. Boston: MIT Press.

Christensen, C. M. \& Raynor, M. E. 2003. Why Hardnosed Executives Should Care about Management Theory. Harvard Business Review, 81(9): 66-74.

Davenport, C. 2016. The Inside Story of How Billionaires are Racing to Take You to Outer Space. The Washington Post, August 19.

Davenport, C. 2018. The Space Barons: Elon Musk, Jeff Bezos, and the Quest to Colonize the Cosmos. New York: Public Affairs.

Diamandis, P. H. \& Kotler, S. 2012. Bold: How to Go Big, Create Wealth, and Impact the World. New York: Simon \& Schuster.

Eisenhardt, K., Graebner, M. \& Sonenshein, S. 2016. Grand Challenges and Inductive Methods: Rigor Without Rigor Mortis. Academy of Management Journal, 59(4): 1113-1123.

https://doi.org/10.5465/amj.2016.4004

Fernholz, T. 2018. Rocket Billionaires: Elon Musk, Jeff Bezos, and the New Space Race. Boston: Houghton Mifflin Harcourt.

Gawer, A. \& Cusumano, M. A. 2014. Industry Platforms and Ecosystem Innovation. Journal Of Product Innovation Management, 31(3): 417-433. https://doi.org/10.1111/jpim.12105

Hayward, M. L., Shepherd, D. A., \& Griffin, D. 2006. A Hubris Theory of Entrepreneurship. Management Science, 52(2): 160-172.

http://dx.doi.org/10.1287/mnsc.1050.0483

Jennings, J., Jennings, P. \& Sharifian, M. 2016. Living the Dream? Assessing the "Entrepreneurship as Emancipation" Perspective in a Developed Region. Entrepreneurship Theory and Practice, 40(1): 81-110. https://doi.org/10.1111/etap.12106

March, J. G., Sproull, L. S. \& Tamuz, M. 1991. Learning from Samples of One or Fewer. Organization Science, 2(1): 1-13.

http://dx.doi.org/10.1287/orsc.2.1.1

Martin, G. 2017. NewSpace: The Emerging Commercial Space Industry. NASA Technical Report ARC-E-DAATN38624.

Muegge, S. M. 2013. Platforms, Communities, and Business Ecosystems: Lessons Learned about Technology Entrepreneurship in an Interconnected World. Technology Innovation Management Review, 3(2): 5-15.

http://doi.org/10.22215/timreview/655

Muegge, S. M. \& Reid, E. 2018. Richard Branson and
Virgin Galactic: A Case Study of Entrepreneuring as Emancipation. In: Proceedings of the 2018 Portland International Conference on Management of Engineering and Technology (PICMET '18, August 1923, Honolulu, Hawaii, USA).

Muegge, S. M. \& Reid, E. 2019. Elon Musk and SpaceX: A Study of Entrepreneuring as Emancipation. Proceedings of ISPIM Connects Ottawa (April 7-10, Ottawa, Canada).

Musk, E. 2017. Making Humans a Multi-planetary Species. New Space, 5(2): 46-61.

https://doi.org/10.1089/space.2017.29009.emu

O'Callaghan, J. 2019. SpaceX's Crew Dragon Spacecraft Just Docked with the International Space Station, Forbes, March 3.

Pekkanen, S. 2016. What Does it Take to Compete in NewSpace? Forbes, June 28.

Poole, M., Van de Ven, A., Dooley, K., \& Holmes, M. 2000. Organizational Change and Innovation Processes: Theory and Methods for Research. Oxford: Oxford University Press.

Reid, E. 2018a. Emancipated Entrepreneuring in the Nascent Commercial Spaceflight Industry: Authoring Ecosystems by Branson, Diamandis, and Musk. Master of Applied Science Thesis. Carleton University.

Reid, E. 2018b. Shoot for the Moon: Why Canada Must Become a Leader in Space. The Globe and Mail, February 25.

Reid, E. 2019. Canada is Going to the Moon -and It's About Time. The Globe and Mail, March 4.

Rindova, V., Barry, D. \& Ketchen, J. 2009. Entrepreneuring as Emancipation. Academy of Management Review, 34(3): 477-491.

https://doi.org/10.5465/amr.2009.40632647

Sarasvathy, S. D. 2001. Causation and Effectuation: Toward a Theoretical Shift from Economic Inevitability to Entrepreneurial Contingency. Academy of Management Review, 26(2): 243-263. http:/ /dx.doi.org/10.5465/AMR.2001.4378020

Schumpeter, J.A. 1942. Capitalism, Socialism and Democracy. London: Routledge.

Suddaby, R. 2010. Editor's Comments: Construct Clarity in Theories of Management and Organization. Academy of Management Review, 35(3): 346-357. http://dx.doi.org/10.5465/AMR.2010.51141319

Van de Ven, A. 2007. Engaged Scholarship: A Guide for Organizational and Social Research. Oxford: Oxford University Press.

Vance, A. 2015. Elon Musk: Tesla, SpaceX, and the Quest for a Fantastic Future. New York: Harper Collins.

Vance, A. 2017. Elon Musk: Tesla, SpaceX, and the Quest for a Fantastic Future. Paperback edition. New York: Harper Collins. 


\section{Elon Musk and SpaceX}

\section{Steven Muegge and Ewan Reid}

Wall, M. 2019. SpaceX Crew Dragon Splashes Down in Atlantic to Cap Historic Test Flight. Space.com, March 8.

Yin, R. 2014. Case Study Research: Design and Methods. 5th edition. Thousand Oaks: Sage Publications.

Zubrin, R. 2013. Mars Direct: Space Exploration, the Red Planet, and the Human Future. Lakewood: Polaris Books.

\section{About the Authors}

Steven Muegge is an Associate Professor of Entrepreneurship at Carleton University in Ottawa, Canada. Dr. Muegge leads an active research program in technology entrepreneurship within the Technology Innovation Management (TIM) program. His research, teaching, and community service interests include platforms, communities, and business ecosystems, and the business models of technology entrepreneurs, especially in early-stage product-market spaces. Dr. Muegge holds a Bachelor of Engineering degree in Engineering Physics from McMaster University, a Master of Engineering degree in Telecommunications Technology Management from Carleton University, and a Ph.D. in Management from Carleton University.

Ewan Reid is President and CEO of Mission Control Space Services, a space exploration and robotics company with a focus on mission operations, onboard autonomy, and artificial intelligence. Prior to founding Mission Control, Ewan worked at a major Canadian space company as a systems designer and project manager. He has been a subsystem design lead on three rover prototypes for the Canadian Space Agency, a systems and electrical designer and operations engineer on the Space Shuttle Program, and a mission controller for ten Space Shuttle missions at NASA. Ewan has degrees in Electrical Engineering and Economics from Queen's University and a Master's degree in Technology Innovation Management from Carleton University.

Citation: Muegge, S. \& E. Reid. 2019. Elon Musk and SpaceX: A Case Study of Entrepreneuring as Emancipation. Technology Innovation Management Review, 9(8): 18-29.

http://doi.org/10.22215/timreview/ 1258

Keywords: Elon Musk; SpaceX; NewSpace; technology entrepreneurship; entrepreneuring as emancipation; seeking autonomy; authoring; declarations. 